\title{
Waste assessment in distribution and marketing logistics of horticultural products: evidence from Brazil
}

\section{Evaluación de residuos en logística de distribución y comercialización de productos hortícolas: evidencias en Brasil}

\author{
Dag Mendonça Lima ${ }^{1^{*}}$, Andréa Leda Ramos de Oliveira ${ }^{1,2}$ \\ Originales: Recepción: 10/06/2020 - Aceptación: 07/04/2021
}

\begin{abstract}
Worldwide, one-third of the food produced is inconsumable due to marketable quality losses. Parallelly, and given the growing world population, levels of waste have become unacceptable. Supply channels play a fundamental role in establishing strategies for food waste mitigation. The objective of this research was to analyze if good operational practices with different dimensions of distribution and commercialization logistics may contribute to reduce fruit and vegetable waste. The studied dimensions were: logistics, operations, technology, trade and management. Several questionnaires were administered to 83 specialized wholesale merchants from a large supply center in Brazil, for lettuce, potato, orange, papaya and tomato. The results indicated that for papaya and potato, low and high waste generation are associated with a greater number of anti-waste actions ( $p=0.0071$ and $p=0.0469$ respectively). For tomato, lettuce and orange, no significant differences for high and low waste in relation to the number of actions undertaken in these chains, was found. These results represent a first approach to understanding the reasons for food waste at wholesale centers.
\end{abstract}

\section{Keywords}

food waste $\bullet$ supply chain management $\bullet$ waste minimization • sustainable marketing • fruit surplus $\bullet$ waste prevention

1 University of Campinas. LOGICOM. Agroindustrial Logistics and Commercialization Laboratory. School of Agricultural Engineering. Av. Cândido Rondon. 501, 13083875. Campinas. S. P. Brazil. University of Campinas (UNICAMP). Center for Food Studies and Research (NEPA). Albert Einstein. 291, 13083-852. Campinas, S. P. Brazil.* limadm@unicamp.br

2 University of Campinas (UNICAMP). School of Agricultural Engineering (FEAGRI). Cândido Rondon. 501. 13083-875. Campinas. S. P. Brazil. aleda@unicamp.br 


\section{RESUMEN}

A nivel mundial, un tercio de los alimentos producidos no se consume debido a la pérdida de calidad para la comercialización, y con la creciente población mundial, los niveles de desperdicio son inaceptables. Los canales de suministro juegan un papel fundamental en la mitigación del desperdicio de alimentos y en el establecimiento de estrategias para reducirlo. El objetivo de esta investigación fue analizar si las buenas prácticas operativas de diferentes dimensiones de la logística de distribución y comercialización contribuyen a reducir los niveles de desperdicio de frutas y hortalizas. Las dimensiones fueron: logística, operaciones, tecnología, comercio y gestión. Los cuestionarios fueron administrados a 83 comerciantes mayoristas especializados de un gran centro de suministro en Brasil para lechuga, papa, naranja, papaya y tomate. Los resultados indican que, para papaya y papa, bajo y alto desperdicio están asociados con el mayor número de acciones realizadas por los comerciantes ( $\mathrm{p}=0,0071$ y $\mathrm{p}=0,0469$ respectivamente). Para tomate, lechuga y naranja, no hay evidencia significativa de diferencias para alto y bajo desperdicio y el número de acciones tomadas en estas cadenas. Los resultados obtenidos en esta investigación representan un primer acercamiento para comprender las razones del desperdicio de alimentos en los centros mayoristas.

\section{Palabras clave}

desperdicio de alimentos • gestión de la cadena de suministro $\bullet$ minimización de desperdicios $\bullet$ comercialización sostenible $\bullet$ excedente de frutas $\bullet$ prevención de desperdicios

\section{INTRODUCTION}

Food loss and waste generation persist as world essential challenges. Approximately one-third of globally produced food, is not consumed. This is largely due to loss of quality for marketing and/or consumption. Given the relentless growth of the world population, these unacceptable levels cause financial and nutritional losses worldwide $(5,19,40,41)$.

Research on causal agents like management mechanisms and quantification of food loss/ waste levels, as well as on efficient actions promoting food loss/waste reduction, should be considered and approached (2). According to Abiad and Meho (2018), information on food loss and waste is still limited to specific investigations, and in many cases, sampling design does not allow results generalization or even comparisons among studies.

Reducing food loss and waste contributes to increasing food supply by reducing the need to complement its availability through public policies or even through commercial imports and donations. Higher food availability contributes to lowering prices, implying, under normal market conditions, lower prices for final consumers $(14,36,42)$.

Conceptually, food loss refers to the reduction in the amount of available edible food throughout its production chain. Waste, in turn, constitutes losses in retail and/or caused by the final consumer. Only products intended for human consumption are considered waste, excluding inedible parts and animal feed. Food intended for human consumption but used, for instance, in bioenergy, still constitutes a loss (19). The causes of food loss and waste generation are mainly related to financial, managerial, and technological limitations during harvest, postharvest and storage, packaging systems and marketing infrastructure (22). In the distribution and commercialization logistics, food degradation affects all stages, from production, harvest and postharvest, to processing, distribution and sales $(3,5,26$, $31,37,45)$. According to Cunha (2015), loss is also associated with pathogen attack in cooling chambers and packages, budding in roots and tubers, and advanced maturation. Postharvest losses and quality deterioration of fruit and vegetable crops are mainly caused by pests, microbial infection, natural ripening, and environmental conditions such as heat, drought, moisture, and improper postharvest management $(35,45)$. Marketing channels, especially short channels, hold importance since they reduce transaction costs by mediating contact between growers and final consumers (24). However, these channels are inherent to intermediary agents and actors involved in product sales (9). A marketing channel allows growers to reach various distribution centers, such as fairs, industries, industrial centers, 
cooperatives, events and even to export their products overseas, increasing marketing reach (43). Identifying the distribution/commercialization stages with the highest levels of waste generation, allows a more efficient management of the supply chain, with lower levels of associated loss $(5,34)$.

In Europe, initiatives for accurately quantifying waste in the main economic sectors, are increasing. In 2012, the European Union, estimated food retail waste at 5 million tons $(5,38)$. In these countries, the food retail sector accounts for approximately $5 \%$ of total food waste in the entire food chain. This sector was responsible for wasting $2 \%$ of food in the United Kingdom and about 2 to $4 \%$ in Poland, Germany and Sweden $(18,20)$. In Latin America, initiatives regarding food waste are still modest, failing to quantify food waste among the different food systems. According to FAO (2016), Latin America and the Caribbean are responsible for $6 \%$ of global food losses. In these regions, $15 \%$ of food for human consumption is wasted each year (21). According to Parfitt et al. (2010), small retailers, especially those not connected to other chains, are more likely to generate higher volumes of food waste given their limited resources and inadequate customer demand forecasting. Therefore, management and maintenance of supplier-customer relationships cannot guarantee food delivery and reduced waste in food retailing.

Kummu et al. (2012), after assessing waste generation at different stages through the chain for different countries, classified them into two groups: middle- to high-income countries, with more than $50 \%$ of waste associated with distribution and consumption, and low-income countries, where the most waste is associated with production and postharvest. These same authors indicated that cereals account for $57 \%$ of total losses in the food supply chain, fruit and vegetables, for 39\%, and roots and tubers, for 33\%. The highest levels of food loss and waste in absolute terms are associated with industrialized Asia and South and Southeast Asia (29). In this sense, Affognon et al. (2015), when assessing food waste through meta-analysis, indicated that waste of roots and tubers, and fruit and vegetables in sub-Saharan Africa were estimated at 33 to $60 \%$ and 37 to $55 \%$, respectively. In the same sense, Stensgard et al. (2016), when assessing food waste during 2010-2015 in Norway, indicated that, considering the volume of wholesale sales, percentages of food waste decreased as a result of increased sales. Among the evaluated groups, fruit and vegetables showed the highest waste generation, resulting, for the analyzed period, in between 1.0 and $1.03 \%$ of wholesale sales.

Nonetheless, controlling key physiological aspects that contribute to the loss of quality of fruit and vegetables in the distribution and marketing chains contributes to reducing commercial loss, increasing food supply for human consumption. Thus, the objective of this study was to evaluate how the logistics, operations, technology, trade, and management dimensions may interrelate with each other affecting waste production, given that the analysis of only one dimension cannot properly evaluate food waste in its entirety.

\section{MATERIALS AND METHODS}

The chosen methodology was based on a semi-structured questionnaire administrated to wholesale merchants of the Campinas Supply Center - CEASA Campinas (2018). This methodological approach, known as rapid assessment or quick appraisal (17), Kumar (1993), Dunn (1994) and Beebe (1995) is founded on data obtained from secondary sources along with semi-structured interviews in which more detailed data and/or information is required to understand the dynamics of the sector assessed.

The five chosen products (orange, papaya, lettuce, tomato and potato) and their respective categories, namely (1) fruit, (2) leaf, flower and stem vegetables, and (3) root, bulb, tuber and rhizome, are among the most consumed by the Brazilian population, according to the latest Family Budget Survey - POF 2008 - 2009 (13, 27). According to the POF 2008-2009, orange and papaya consumption is 2.807 and $2.045 \mathrm{~kg} /$ capita/year, respectively, second only to watermelon (3.368 kg/per capita/year) (27). Tomato consumption is $4.916 \mathrm{~kg} / \mathrm{capita} / \mathrm{year}$, first in the fruit group. In the leaf group, lettuce consumption is $0.91 \mathrm{~kg} / \mathrm{capita} / \mathrm{year}$, behind cabbage with $1.032 \mathrm{~kg} / \mathrm{capita} /$ year. Finally, ranking first in the tuber vegetables group, consumption of potato is around $4.037 \mathrm{~kg} /$ capita/year (27). Twelve wholesale merchants 
were interviewed for lettuce, 15 for potato, 14 for orange, 19 for papaya and 23 for tomato, comprising a total of 83 wholesale merchants. To maintain anonymity, merchants were coded by sequential numbers from 1 to 83 .

The administrated questionnaires referring to business practices, storage, transport conditions, postharvest treatment and management, provision and delivery of services, marketing and after-sales strategies, were administered during the second half of 2018. During data collection, each wholesale merchant was asked to report the amount of waste associated with each product. Thus, the declared waste depended on each wholesale merchant, functioning as waste estimator during trade and distribution logistics.

Seventeen variables related to marketing and distribution were obtained from the questionnaire, providing a positive $(+)$ or negative $(-)$ relationship with food waste depending on their association with the distribution and commercialization logistics chain (table 1). Values of 1 (yes) or 0 (no) were associated to each variable indicating if wholesale traders carried out such procedure in the logistics chain of the analyzed product.

Table 1. Description of variables collected from CEASA-Campinas wholesale merchants and used for analysis.

Tabla 1. Descripción de las variables recopiladas de los comerciantes mayoristas CEASA-Campinas y utilizadas para el análisis.

\begin{tabular}{|c|c|c|}
\hline Variable & Description & $\begin{array}{l}\text { Contribution } \\
\text { to or loss }\end{array}$ \\
\hline Handling during trade & To identify procedures assessing product quality status. Represented by “tipman”. & - \\
\hline Transshipment operations & To identify transshipment operations. Represented by "oprtrans". & + \\
\hline Package trading & To identify packaging in product marketing . Represented by “comtpemb”. & - \\
\hline Product quality control & To identify product quality control . Represented by "tipcotr". & - \\
\hline Supplying package & To identify packaging supply for the producer or buyer. Represented by “fornemb”. & - \\
\hline $\begin{array}{l}\text { Classification and reclassification } \\
\text { operations of sold products }\end{array}$ & $\begin{array}{l}\text { To identify product classification and/or reclassification procedures. Represented by } \\
\text { "clarecla". }\end{array}$ & - \\
\hline Cooling chamber & To identify the use of a cold chamber. Represented by "camfria". & - \\
\hline Postharvest treatment & $\begin{array}{l}\text { To identify postharvest treatments such as wax, application of fungicides, or drying, } \\
\text { among others. Represented by "tratpos". }\end{array}$ & - \\
\hline Transport type & To identify chosen transport Represented by "tiptrns". & - \\
\hline Provision of service & $\begin{array}{l}\text { To identify customer services (consignment of products, exhibitors). Represented by } \\
\text { "tipreserv". }\end{array}$ & - \\
\hline Promotional pricing & To identify promotional pricing. Represented by "prcprom". & - \\
\hline Price tracking & To identify if the wholesaler follows price movements. Represented by "acmovpr". & - \\
\hline Purchase by contract & $\begin{array}{l}\text { To identify the sale, such as a contract and contractual requirement. Represented by } \\
\text { "comp". }\end{array}$ & - \\
\hline Purchase by opportunity & To identify purchase opportunity. Represented by “compop”. & + \\
\hline Alternate destinations & $\begin{array}{l}\text { To identify whether unsold products are discarded or donated to institutions such as } \\
\text { food bank and charities. Represented by "destcomr". }\end{array}$ & - \\
\hline Waste control & To identify waste control. Represented by “cntrdesp”. & - \\
\hline Fixed producer/supplier & $\begin{array}{l}\text { To identify whether the products sold are supplied by fixed producers or suppliers. } \\
\text { Represented by "pffixo". }\end{array}$ & - \\
\hline
\end{tabular}


When defining analyses dimensions such as the representation of a group, to assume that causal relationships for waste analysis are multi-factorial and dynamic, is possible. Thus, in order to evaluate the relationship between variables and practices/conducts on the evaluated fruit and vegetable waste generation, five dimensions were defined $(33,46)$.

Given this context, these dimensions constituted a form of representation capable of sorting various elements for analysis, considering a complex and multi-factorial intersection between waste, established variables, chain actors, their practices and procedures, and the fruit and vegetable analyzed. The five defined dimensions were: logistics, operations, technology, trade and management (figure 1). Based on a self-declared value of waste and an average value (obtained by the arithmetic mean of all values reported by wholesale merchants), wholesale merchants were grouped into "high" or "low" level of food waste for each product. The database was created considering response frequency and leading to proportions. Descriptive analyses of variables and dimensions were performed for each of the five products evaluated.

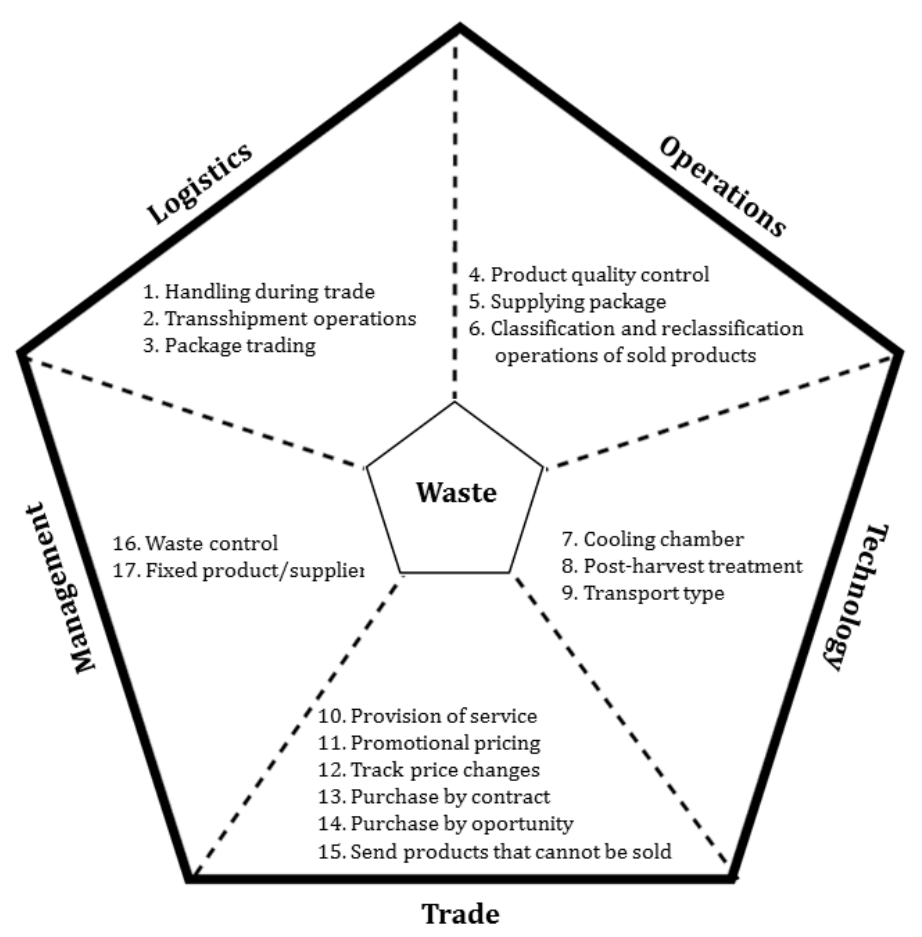

Figure 1. Dimensions and associated variables.

Figura 1. Dimensiones y variables asociadas.

\section{Statistical analysis}

To test the hypothesis stating that "the distribution of the number of waste preventive actions is the same for groups with low and high waste", the Wilcoxon-Mann-Whitney non-parametric test was performed for each product.

The analyses were performed with $\mathrm{R}$ software version 4.0 .2 , aided by the coin package $(23,39,47)$. A significance level of $5 \%$ was considered for all tests.

\section{RESUlts}

For high waste and for all evaluated products, the highest averages for declared waste were observed with the smallest number of preventive or anti-waste actions. Among all evaluated products, potato stood as the one with the least actions (49 shares) (table 2, page 212). 
Table 2. Frequency for the group of high waste.

Tabla 2. Frecuencia para el grupo de residuos altos.

\begin{tabular}{|c|c|c|c|c|c|}
\hline Dimension/Variables & Papaya & Potato & Lettuce & Orange & Tomato \\
\hline Logistics & 18 & 12 & 14 & 9 & 21 \\
\hline Tipman & 6 & 1 & 5 & 2 & 5 \\
\hline Oprtrans & 5 & 4 & 5 & 2 & 6 \\
\hline Comtpemb & 7 & 7 & 4 & 5 & 10 \\
\hline Operations & 16 & 3 & 13 & 9 & 18 \\
\hline tipcotr & 5 & 2 & 5 & 3 & 3 \\
\hline fornemb & 2 & 0 & 4 & 3 & 9 \\
\hline clarecla & 9 & 1 & 4 & 3 & 6 \\
\hline Technology & 19 & 6 & 14 & 9 & 13 \\
\hline camfria & 6 & 0 & 3 & 1 & 1 \\
\hline tratpos & 6 & 6 & 6 & 4 & 6 \\
\hline tiptrns & 7 & 0 & 5 & 4 & 6 \\
\hline Trade & 40 & 22 & 26 & 23 & 43 \\
\hline tipreserv & 4 & 3 & 1 & 4 & 6 \\
\hline prcprom & 6 & 4 & 6 & 3 & 10 \\
\hline acmovpr & 8 & 4 & 5 & 4 & 10 \\
\hline comp & 7 & 3 & 6 & 4 & 5 \\
\hline compop & 6 & 3 & 3 & 3 & 2 \\
\hline destcomr & 9 & 5 & 5 & 5 & 10 \\
\hline Management & 13 & 6 & 9 & 7 & 14 \\
\hline cntrdesp & 7 & 4 & 4 & 4 & 7 \\
\hline pffixo & 6 & 2 & 5 & 3 & 7 \\
\hline Average waste & 8.4 & 9.8 & 27.4 & 3.3 & 6.5 \\
\hline Total shares & 106 & 49 & 76 & 57 & 109 \\
\hline Minimum number of shares & 9 & 5 & 10 & 9 & 7 \\
\hline Maximum number of shares & 14 & 11 & 15 & 15 & 13 \\
\hline
\end{tabular}

For low waste and all evaluated products, the highest averages for declared waste were observed when the largest number of anti-waste actions were performed. Tomato and papaya resulted to have the highest number of shares, with 109 and 106 shares, respectively (table 3, page 213).

Orange and papaya wholesalers carried out the largest number of anti-waste actions (80\%), with reported low levels of residues of $1.3 \%$ and $3.5 \%$, respectively (figure 2, page $213-214)$. The high waste generation rates for orange $(3.3 \%)$ and papaya $(8.4 \%)$ were observed for the fewest waste avoiding actions ( $60 \%$ for orange and $67 \%$ for papaya).

Low levels of waste for tomato $(0.8 \%)$ and lettuce $(16.6 \%)$ were observed when wholesale traders carried out the most anti-waste actions, with $67 \%$ for tomato and $72 \%$ for lettuce (figure 2, page 213-214). Wholesale traders with the highest waste of tomato $(6.5 \%)$ and lettuce $(27.4 \%)$ were the ones that carried out the fewest anti-waste actions (64\%) (figure 2, page 213-214).

Wholesale potato traders with low declared waste $(2.4 \%)$ and high declared waste $(9.8 \%)$ carried out $60 \%$ and $41 \%$ of anti-waste actions, respectively. Among all the considered products, wholesale potato traders were the ones performing the fewest preventive actions (figure 2, page 213-214).

The highest waste generation rate reported by wholesale traders was observed for lettuce (average 22.5\%). The lowest level of waste was observed for orange (average of $2.2 \%$ ). Papaya and potato resulted to have an average level of waste of $5.8 \%$, while tomato showed 3.3\% (figure 3, page 214).

For low papaya waste, the lowest frequencies were observed for the variables purchase opportunity and transshipment operation, with $30 \%$ and 40\%, respectively (figure 4, page 214).

The highest frequencies of the management and trade variables were observed for low lettuce waste, resulting in 100 and 80\%, respectively (figure 4, page 214). 
Table 3. Frequency for the group of low waste.

Tabla 3. Frecuencia para el grupo de bajo residuo.

\begin{tabular}{|c|c|c|c|c|c|}
\hline Dimension/Variables & Papaya & Potato & Lettuce & Orange & Tomato \\
\hline Logistics & 20 & 11 & 11 & 23 & 27 \\
\hline tipman & 7 & 3 & 3 & 8 & 12 \\
\hline oprtrans & 3 & 0 & 2 & 6 & 2 \\
\hline comtpemb & 10 & 8 & 6 & 9 & 13 \\
\hline Operations & 24 & 8 & 8 & 24 & 26 \\
\hline tipcotr & 10 & 4 & 4 & 9 & 5 \\
\hline fornemb & 6 & 1 & 4 & 6 & 9 \\
\hline clarecla & 8 & 3 & 0 & 9 & 12 \\
\hline Technology & 25 & 16 & 15 & 18 & 20 \\
\hline camfria & 10 & 1 & 4 & 6 & 3 \\
\hline tratpos & 7 & 8 & 6 & 9 & 10 \\
\hline tiptrns & 8 & 7 & 5 & 3 & 7 \\
\hline Trade & 50 & 34 & 30 & 41 & 53 \\
\hline tipreserv & 8 & 4 & 4 & 2 & 8 \\
\hline prcprom & 10 & 7 & 6 & 8 & 13 \\
\hline acmovpr & 9 & 7 & 6 & 8 & 13 \\
\hline comp & 9 & 8 & 5 & 6 & 6 \\
\hline compop & 4 & 0 & 3 & 8 & 1 \\
\hline destcomr & 10 & 8 & 6 & 9 & 12 \\
\hline Management & 18 & 12 & 12 & 15 & 21 \\
\hline cntrdesp & 10 & 0 & 6 & 6 & 10 \\
\hline pffixo & 8 & 8 & 6 & 9 & 11 \\
\hline Average waste & 3.5 & 2.4 & 16.6 & 1.3 & 0.7 \\
\hline Total shares & 137 & 81 & 106 & 121 & 147 \\
\hline Minimum number of shares & 12 & 9 & 11 & 11 & 7 \\
\hline Maximum number of shares & 15 & 13 & 15 & 14 & 14 \\
\hline
\end{tabular}
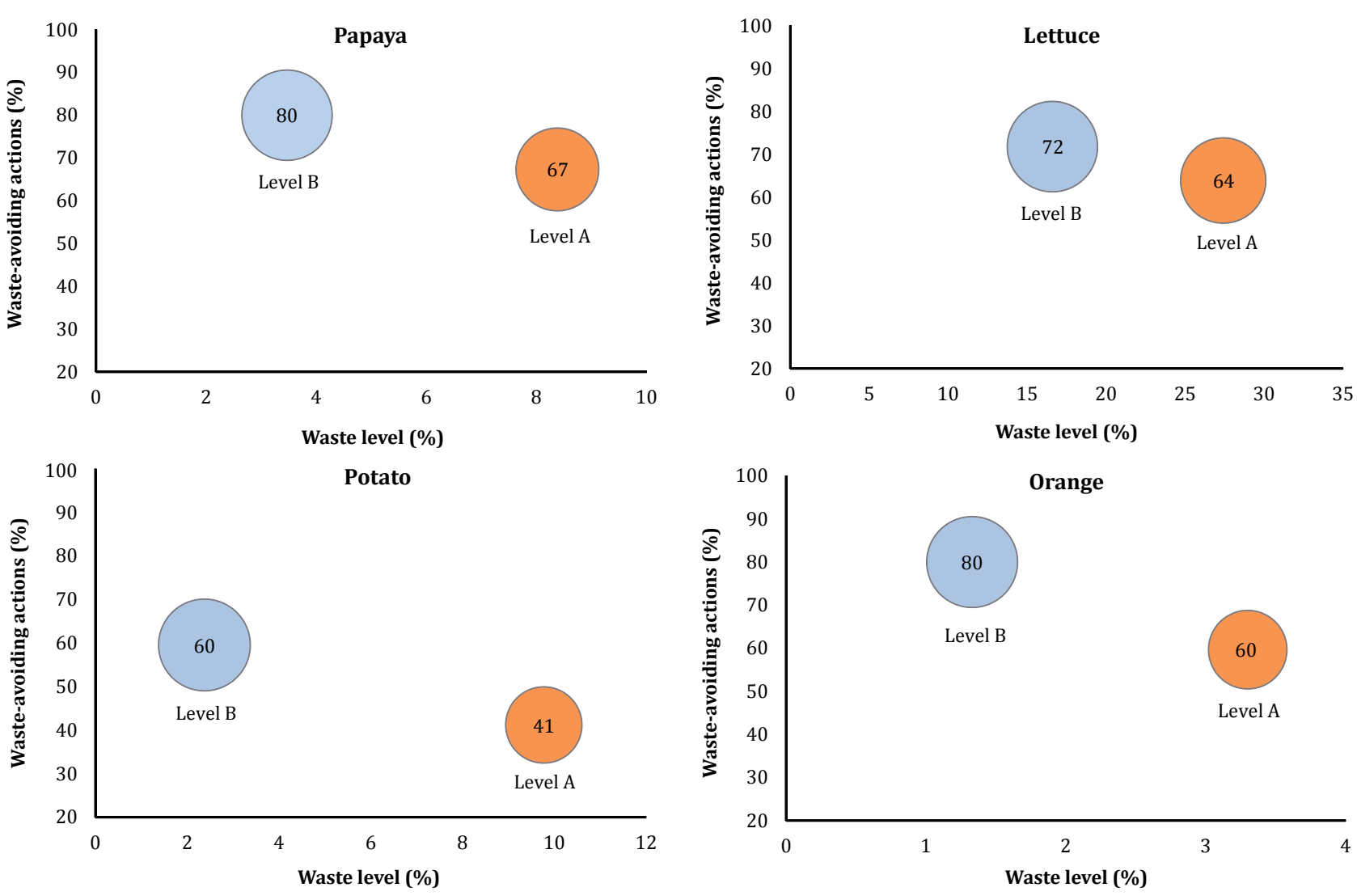

Figure 2. Levels of declared waste and number of anti-waste actions.

Figura 2. Niveles de residuos declarados y número de acciones que evitan los residuos. 


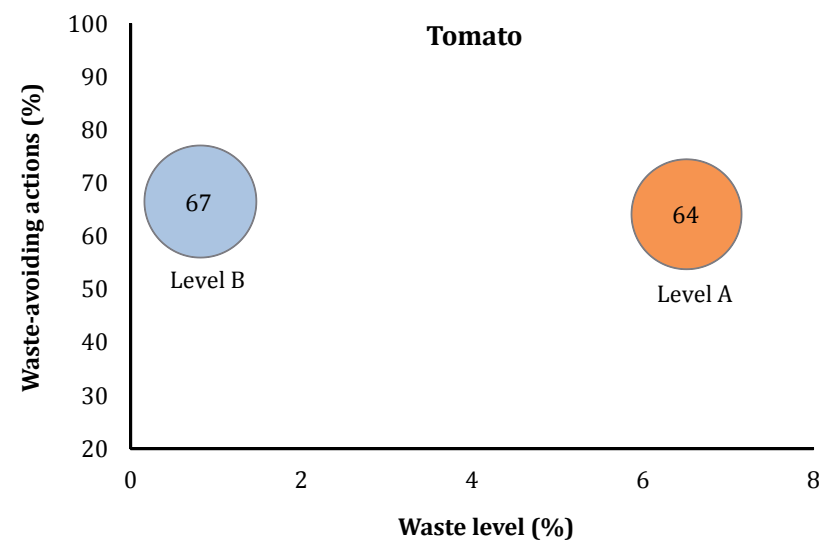

Figure 2 (cont.). Levels of declared waste and number of anti-waste actions.

Figura 2 (cont.). Niveles de residuos declarados y número de acciones que evitan los residuos.

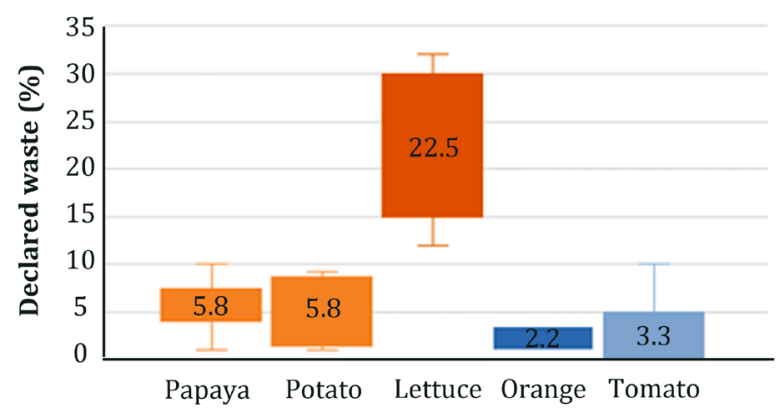

Figure 3. Declared waste of evaluated fruit and vegetables.

Figura 3. Desecho declarado de las frutas y verduras evaluadas.

\section{$\leadsto$ Papaya high declarede waste $\quad \rightarrow$ Papaya low declarede waste}

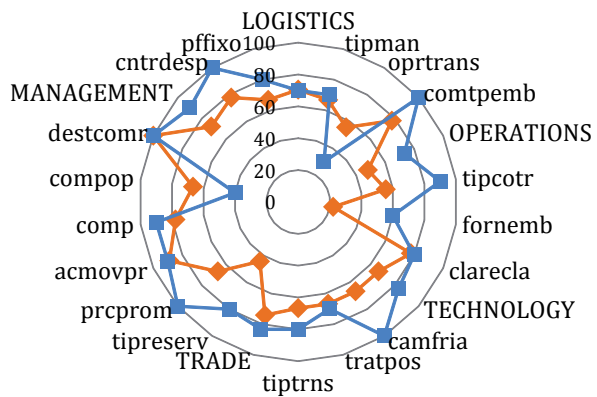

$\sim$ Lettuce high declarede waste $\quad-$-Lettuce low declarede waste

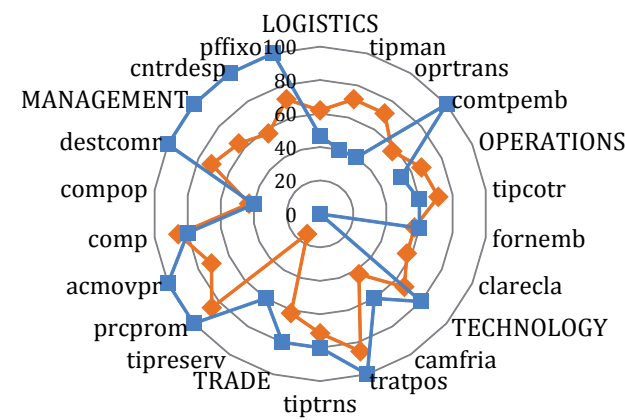

Legend: tipman: trade handling operations, oprtrans: transshipment operations, comtpemb: package trading, tipcotr: type of control for traded products, fornemb: supplying package, clarec: classification and reclassification operations of sold products, camfria: cooling chamber, tratpos: postharvest treatment, tiptrns: transport type, tipreserv: provision of services, precprom: promotional pricing, acmovpr: track price changes, comp: purchase by contract, compop: purchase by opportunity, destcomer: unsoldable sent products, contrdesp: waste control, pffixo: fixed producer or supplier.

Leyenda: tipman: operaciones de manipulación comercial, oprtrans: operaciones de transbordo, comtpemb: comercio de paquetes, tipcotr: tipo de control para productos comercializados, fornemb: paquete de suministro, clarec: operaciones de clasificación y reclasificación de productos vendidos, camfria: cámara de enfriamiento, tratpos: poscosecha tratamiento, tiptrns: tipo de transporte, tipreserv: prestación de servicios, precprom: precios promocionales, acmovpr: seguimiento de cambios de precio, comp: compra por contrato, comp: compra por oportunidad, destcomer: productos enviados no soldables, contrdesp: control de residuos, pffixo: fijo productor o proveedor.

Figure 4. Percentage contributions of dimensions and indicators to papaya and lettuce waste levels.

Figura 4. Contribuciones porcentuales de dimensiones e indicadores a los niveles de residuos de papaya y lechuga. 
For low potato waste, the highest frequencies were observed for management and trade, 80 and $70 \%$, respectively (figure 5).

$\rightarrow$ Potato high declarede waste $\quad-$-Potato low declarede waste

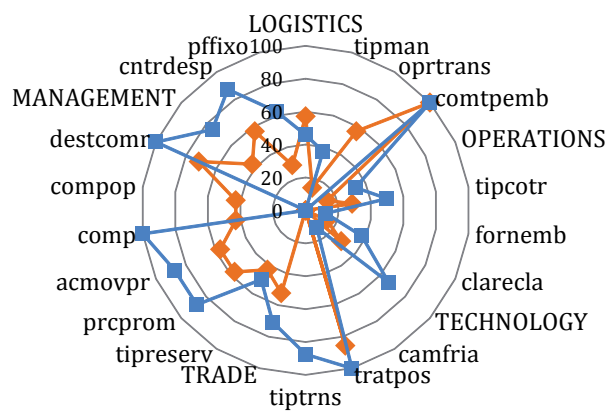

$\diamond$ Orange high declarede waste $\quad=$ Orange low declarede waste

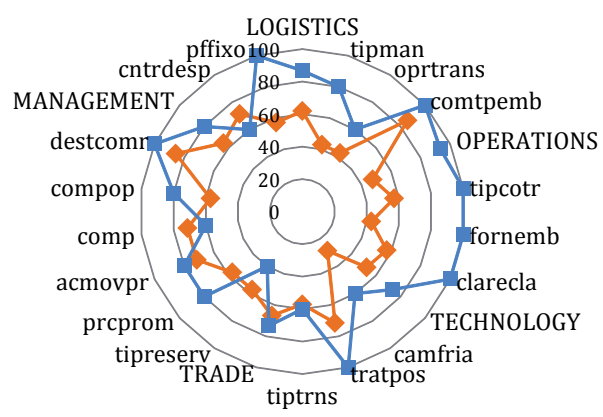

Legend: tipman: trade handling operations, oprtrans: transshipment operations, comtpemb: package trading, tipcotr: type of control for traded products, fornemb: supplying package, clarec: classification and reclassification operations of sold products, camfria: cooling chamber, tratpos: postharvest treatment, tiptrns: transport type, tipreserv: provision of services, precprom: promotional pricing, acmovpr: track price

changes, comp: purchase by contract, compop: purchase by opportunity, destcomer: unsoldable sent products, contrdesp: waste control, pffixo: fixed producer or supplier.

Leyenda: tipman: operaciones de manipulación comercial, oprtrans: operaciones de transbordo, comtpemb: comercio de paquetes, tipcotr: tipo de control para productos comercializados, fornemb: paquete de suministro, clarec: operaciones de clasificación y reclasificación de productos vendidos, camfria: cámara de enfriamiento, tratpos: poscosecha tratamiento, tiptrns: tipo de transporte, tipreserv: prestación de servicios, precprom: precios promocionales, acmovpr: seguimiento de cambios de precio, comp: compra por contrato, comp: compra por oportunidad, destcomer: productos enviados no soldables, contrdesp: control de residuos, pffixo: fijo productor o proveedor.

Figure 5. Percentage contributions of dimensions and indicators to potato and orange waste levels.

Figura 5. Porcentaje de contribuciones de dimensiones e indicadores a los niveles de desechos de papa y naranja.

The highest frequencies of the operations dimension (93.3\%) and logistics dimension (86.7\%), were observed for orange low waste (figure 5). The highest frequencies in the management dimension were $80.8 \%$ for low tomato waste and $70.0 \%$ for high tomato waste (figure 6).

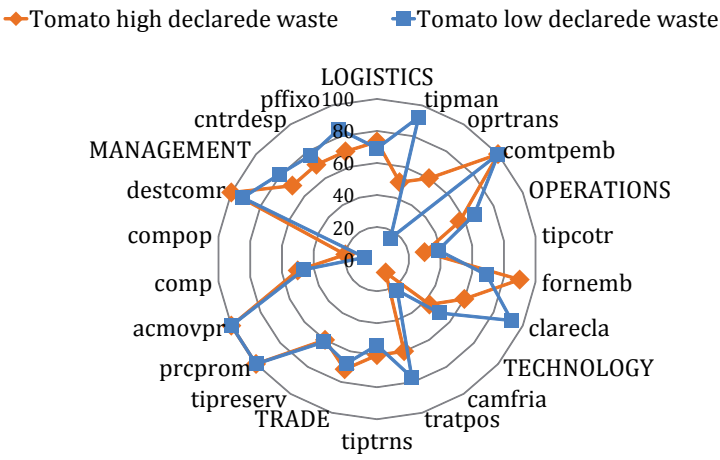

Legend: tipman: trade handling operations, oprtrans: transshipment operations, comtpemb: package trading, tipcotr: type of control for traded products, fornemb: supplying package, clarec: classification and reclassification operations of sold products, camfria: cooling chamber, tratpos: postharvest treatment, tiptrns: transport type, tipreserv: provision of services, precprom: promotional pricing, acmovpr: track price changes, comp: purchase by contract, compop: purchase by opportunity, destcomer: unsoldable sent products, contrdesp: waste control, pffixo: fixed producer or supplier.

Leyenda: tipman: operaciones de manipulación comercial, oprtrans: operaciones de transbordo, comtpemb: comercio de paquetes, tipcotr: tipo de control para productos comercializados, fornemb: paquete de suministro, clarec: operaciones de clasificación y reclasificación de productos vendidos, camfria: cámara de enfriamiento, tratpos: poscosecha tratamiento, tiptrns: tipo de transporte, tipreserv: prestación de servicios, precprom: precios promocionales, acmovpr: seguimiento de cambios de precio, comp: compra por contrato, comp: compra por oportunidad, destcomer: productos enviados no soldables, contrdesp: control de residuos, pffixo: fijo productor o proveedor.

Figure 6. Percentage contributions of dimensions and indicators to tomato waste levels.

Figura 6. Contribuciones porcentuales de dimensiones e indicadores a los niveles de residuos de tomate. 
For the supply and marketing logistics of papaya and potato, low and high waste were associated with the greater number of actions taken by wholesalers (figure 7). For the distribution and marketing logistics of tomato, lettuce and orange, no significant differences among high and low waste generation and number of anti-waste actions, could be found (figure 7).

Blue asterisks represent mean values, $p$-values were obtained by the Wilcoxon-MannWhitney test.

Asteriscos azules representan el valor medio. Los valores p son resultado de la prueba de Wilcoxon-MannWhitney.
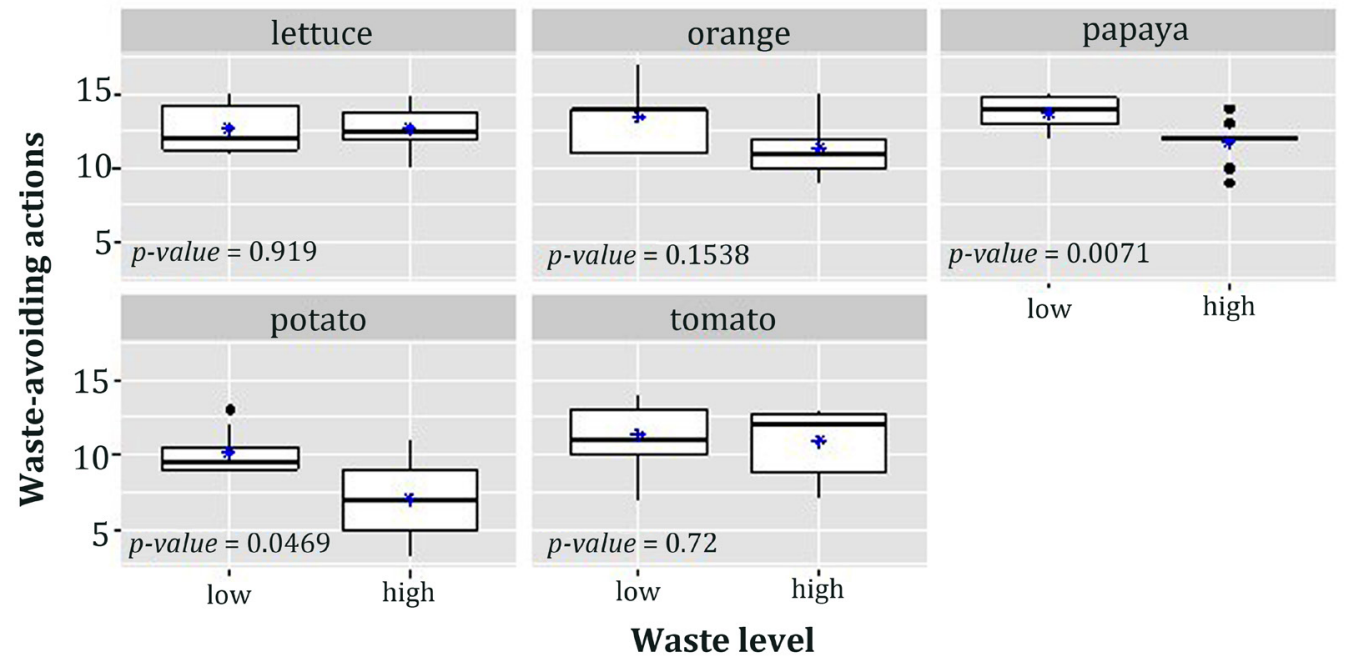

Figure 7. Boxplot of the number of anti-waste actions by level of waste, for each product. Figura 7. Boxplot del número de acciones anti-desperdicio por nivel de desperdicio, por producto. Asteriscos azules representan el valor medio.

\section{Discussion}

For papaya, the low content of declared waste resulted to be associated with the use of cardboard boxes, plastics and other types of packaging, as well as the use of cooling chambers that contribute to a slower cellular metabolism and longer storage. On the other hand, some practices such as transshipment operations, open truck transport (often covered with canvas) and the use of "K" type packaging (wood), were associated with higher waste levels.

Potato, with the same declared waste level as papaya, also shares inadequate storage and commercialization. Load stacking and the volume of potato packages $(20 \mathrm{~kg}$ ) contribute to accelerating tuber metabolism and its consequent deterioration.

The low frequency of operation and management variables contributed to higher waste production for all the evaluated products. Levels of waste in the distribution and supply chains varied according to the product considered and were related to procedures in the distribution and marketing logistics chains. A complex intersection between declared waste, defined variables, wholesalers, and established procedures in the distribution and marketing logistics determine that the highest levels of waste are related to inadequate commercial and logistics practices, technical limitations and inappropriate storage, commerce and transportation infrastructure $(11,19)$. According to Abiad and Meho (2018), equipment, low quality techniques and inadequate handling in the fruit and vegetable chain cause mechanical, physiological and pathological damage. Fruit and vegetable waste is associated, to a greater or lesser extent, with specific conditions of the distribution and marketing logistics, such as: storage, processing, packaging, transportation and marketing $(8,23,32)$. According to Kasso and Bekele (2018), maintaining relative humidity provides longer shelf-life and quality, reducing postharvest losses and deterioration. Other factors such as the use of cooling chambers, plastic or cardboard packaging, storage, adequate transport and shorter distances are also associated with lower levels of waste. The main factors causing postharvest loss and quality deterioration are also related to improper handling, cargo handling operations, inadequate packaging, inappropriate transport, storage, processing and display for sale $(28,38)$. In addition, shared fruit and vegetable transport, or combining different stages of ripeness, may negatively impact quality, accelerating maturation (6). 


\section{Conclusion}

The larger the expanded area of the radar chart formed (figure 4, page 214; figure 5, page 215 and figure 6, page 216) the lower the level of waste declared for papaya and potato. For these products, high and low frequencies of all dimensions are associated with high and low waste, respectively.

For the distribution and marketing logistics of tomato, lettuce and orange, no significant differences for high and low waste in relation to the number of anti-waste actions was found.

Papaya and potato waste generation at CEASA Campinas involve multiple factors and depend on the practices established in the distribution and marketing chains.

Due to the physiology of the fruits and vegetables analyzed, and given post-harvest conditions, some level of food waste is expected. However, to establish good practices aimed at minimizing waste in these chains, is necessary.

Considering the characteristics of each product and the practices established in each distribution and marketing logistics, to compare different products does not lead to an assertive assessment of facts. Since each product demands different and specific conditions of transport, packaging, cooling and storage, a careful analysis of the various dimensions and variables, must be approached.

This work does not represent a definite assessment of waste from the perspective of the CEASA Campinas distribution and marketing logistics. However, it stresses the need to create instruments capable of reliably quantifying food waste, with demands to be met by local public authorities and the industry, in order to minimize fruit and vegetable losses in wholesale markets.

\section{REFERENCES}

1. Abiad, M. G.; Meho, L. I. 2018. Food loss and food waste research in the Arab world: a systematic review. https://doi.org/10.1007/s12571-018-0782-7.

2. Adasme-Berríos, C.; Sánchez, M.; Mora, M.; Díaz, J.; Schnettler, B.; Lobos, G. 2019a. Effects of food-related health concerns and risk perception on the consumption frequency of fresh vegetables. Revista de la Facultad de Ciencias Agrarias. Universidad Nacional de Cuyo. Mendoza. Argentina. 51(2): 289-305.

3. Adasme-Berríos, C.; Sánchez, M.; Mora, M.; Díaz, J.; Schnettler, B.; Lobos, G. 2019b. The gender role on moderator effect of food safety label between perceived quality and risk on fresh vegetables. Revista de la Facultad de Ciencias Agrarias. Universidad Nacional de Cuyo. Mendoza. Argentina. 51(1): 93-109.

4. Affognon, H.; Mutungi, C.; Sanginga, P.; Borgemeister, C. 2015. Unpacking postharvest losses in sub-Saharan Africa: A Meta-Analysis. World Dev. 66:49-68. doi:10.1016/j. worlddev.2014.08.002.

5. Alexander, P.; Brown, C.; Arneth, A.; Finnigan, J.; Moran, D.; Rounsevell, M. D. A. 2017. Losses, inefficiencies and waste in the global food system. Agricultural Systems. 153: 190-200. https://doi.org/10.1016/j.agsy.2017.01.014.

6. Baloch, M. K.; Bibi, F. 2012. Effect of harvesting and storage conditions on the post harvest quality and shelf life of mango (Mangifera indica L.) fruit. South African Journal of Botany. 83: 109-116. https://doi.org/10.1016/J.SAJB.2012.08.001

7. Beebe, J. 1995. Basic concepts and techniques of rapid appraisal. Human Organization. 54(1): 42-51. https://doi.org/10.17730/humo.54.1.k84tv883mr2756l3.

8. Belik, W. 2018. Impasses in transformation of the food system. Journal on Food, Agriculture and Society. 6(2): 5-8. https://www.thefutureoffoodjournal.com/index.php/FOFJ/article/ view/41/31.

9. Belik, W.; Cunha, A. R. A. A.; Costa, L. A. 2012. Crise dos Alimentos e Estratégias para a Redução do Desperdício no Contexto de uma Política de Segurança Alimentar e Nutricional no Brasil. Planejamento e Políticas Públicas. 38: 107-132. http://www.ipea.gov.br/ppp/index.php/ PPP/article/view/277/255.

10. Bilska, B.; Piecek, M.; Kołozyn-Krajewska, D. 2018. A multifaceted evaluation of food waste in a Polish supermarket-Case study. Sustain. 10(9). doi:10.3390/su10093175.

11. Bond, M.; Meacham, T.; Bhunnoo, R.; Benton, T. G. 2013. Food waste within global food systems. Global Food Security Programme. 1-43. https://www.foodsecurity.ac.uk/publications/ food-waste-within-global-food-systems.pdf.

12. CEASA Campinas. 2018. Guia Ceasa Campinas. https://guiaceasacampinas.com.br/adm/ pdf/3863e45a44ac443c211b91a5912908c3.pdf. 
13. CONAB. 2019. Centrais de Abastecimento: Comercialização Total de Frutas e Hortaliças. https://www.conab.gov.br/info-agro/hortigranjeiros-prohort/publicacoes-dosetorhortigranjeiro.

14. Corrado, S.; Caldeira, C.; Eriksson, M.; Hanssen, O. J.; Hauser, H. E.; van Holsteijn, F.; Liu, G.; Östergren, K.; Parry, A.; Secondi, L.; Stenmarck, Å.; Sala, S. 2019. Food waste accounting methodologies: Challenges, opportunities, and further advancements. In Global Food Security. 20: 93-100. Elsevier B.V. https://doi.org/10.1016/j.gfs.2019.01.002.

15. Cunha, A. R. A. A.; Belik, W. 2015. A produção agrícola e a atuação das Centrais de Abastecimento no Brasil. Segurança Alimentar e Nutricional. 19-46. 10.20396/san.v19i1.8634668.

16. Dunn, T. 1994. Rapid Rural Appraisal: A description of the methodology and its application in teaching and research at Charles Sturt University. Rural Society. 4(3-4): 30-36. https://doi. org/10.5172/rsj.4.3-4.30.

17. Ellman, A. 1981. Rapid appraisal for rural project preparation. Agricultural Administration. 8(6): 463-471. https://doi.org/10.1016/0309-586X(81)90040-6

18. Eriksson, M.; Strid, I.; Hansson, P. A. 2016. Food waste reduction in supermarkets - Net costs and benefits of reduced storage temperature. Resour Conserv Recycl.107: 73-81.doi:10.1016/j. resconrec.2015.11.022.

19. FAO. 2011. Global food losses and food waste - Extent, causes and prevention. Rome. http://www. fao.org/3/a-i2697e.pdf.

20. FAO. 2013. Food Wastage Footprint: Impacts on Natural Resources - Summary Report. Rome. www.fao.org/publications. Accessed September 27, 2020.

21. FAO. 2016. Food losses and waste in Latin America and the Caribbbean. Food and Agriculture Organization of the United Nations. (3): 23. <www.fao.org/publications>. Accessed September 27, 2020.

22. Girotto, F.; Alibardi, L.; Cossu, R. 2015. Food waste generation and industrial uses: A review. Waste Management. 45. https://doi.org/10.1016/j.wasman.2015.06.008

23. González-Yebra, O.; Aguilar, M. A.; Aguilar, F. J. 2019. A first approach to the design component in the agri-food industry of southern Spain. Revista de la Facultad de Ciencias Agrarias. Universidad Nacional de Cuyo. Mendoza. Argentina. 51(1): 125-146.

24. Gómez-Luciano, C. A.; De Koning, W.; Vriesekoop, F.; Urbano, B. 2019. A model of agricultural sustainable added value chain: The case of the Dominican Republic value chain. Revista de la Facultad de Ciencias Agrarias. Universidad Nacional de Cuyo. Mendoza. Argentina. 51(1): 111-124.

25. Hollander, M. A.; Wolfe, D.; Chicken, E. 2015. Nonparametric Statistical Methods. $3^{\text {rd }}$ edition. John Wiley \& Sons, Inc. doi:10.1002/9781119196037.

26. Ibarguren, L.; Rebora, C.; Alberto, M. 2018. Harvest time effect on horticultural quality of topinambur (Helianthus tuberosus L.) kept in the soil or in cold storage. Revista de la Facultad de Ciencias Agrarias. Universidad Nacional de Cuyo. Mendoza. Argentina. 50(1): 61-71.

27. Instituto Brasileiro de Geografia e Estatística (IBGE). Pesquisa de Orçamentos Familiares: 2008-2009. Análise do Consumo Alimentar Pessoal no Brasil (IBGE, Ed.) IBGE. [s.l: s.n.]. Disponível em: <http://biblioteca.ibge.gov.br/visualizacao/livros/liv50063.pdf>

28. Kasso, M.; Bekele, A. 2018. Post-harvest loss and quality deterioration of horticultural crops in Dire Dawa Region, Ethiopia. Journal of the Saudi Society of Agricultural Sciences. 17(1): 88-96. https://doi.org/10.1016/J.JSSAS.2016.01.005.

29. Kumar, K. 1993. Rapid appraisal methods. http://documents.worldbank.org/curated/ pt/888741468740959563/pdf/multi0page.pdf

30. Kummu, M.; de Moel, H.; Porkka, M.; Siebert, S.; Varis, O.; Ward, P. J. 2012. Lost food, wasted resources: Global food supply chain losses and their impacts on freshwater, cropland, and fertiliser use. Sci Total Environ. 438: 477-489. doi:10.1016/j.scitotenv.2012.08.092

31. Melo, V. T. P.; Strasburg, V. J. 2020. Geração de resíduos na aquisição de vegetais in natura e minimamente processados por serviço de nutrição e dietética de um hospital público. Brazilian Journal of Food Technology. 23. https://doi.org/10.1590/1981-6723.06919

32. Mrema, C. G.; Rolle, S. R. 2002. Status of the postharvest sector and its contribution to agricultural development and economic growth. In: $9^{\text {th }}$ JIRCAS International Symposium-Value Addition to Agricultural Product. 13-20.

33. Noguera-Talavera, Á.; Salmerón, F.; Reyes-Sánchez, N. 2019. Bases teórico-metodológicas para el diseño de sistemas agroecológicos. Revista de la Facultad de Ciencias Agrarias. Universidad Nacional de Cuyo. Mendoza. Argentina. 51(1): 273-293.

34. Notarnicola, B.; Tassielli, G.; Renzulli, P. A.; Castellani, V.; Sala, S. 2017. Environmental impacts of food consumption in Europe. Journal of Cleaner Production. 140. https://doi.org/10.1016/j. jclepro.2016.06.080.

35. Olayemi, F.; Adegbola, J.; Bamishaiye, E.; Daura, A. 2011. Assessment of post-harvest challenges of small scale farm holders of tomatoes, bell and hot pepper in some local government areas of Kano State, Nigeria. Bayero Journal of Pure and Applied Sciences. 3(2): 39-42. https:// doi.org/10.4314/bajopas.v3i2.63217.

36. Papargyropoulou, E.; Lozano, R. K.; Steinberger, J.; Wright, N.; Ujang, Z. bin. 2014. The food waste hierarchy as a framework for the management of food surplus and food waste. Journal of Cleaner Production. 76: 106-115. https://doi.org/10.1016/j.jclepro.2014.04.020. 
37. Parfitt, J.; Barthel, M.; Macnaughton, S. 2010. Food waste in the global food supply chain is reviewed in relation to the prospects for feeding a population of nine billion by 2050. Philosophical Transactions of the Royal Society B: Biological Sciences. 365(1554): 3065-3081. https:// doi.org/10.1098/rstb.2010.0126.

38. Parmar, A.; Hensel, O.; Sturm, B. 2017. Post-harvest handling practices and associated food losses and limitations in the sweet potato value chain of southern Ethiopia. NJAS - Wageningen. Journal of Life Sciences. 80: 65-74. https://doi.org/10.1016/j.njas.2016.12.002.

39. R Core Team. 2020. R: a language and environment for statistical computing. https://www.gbif. $\mathrm{org} / \mathrm{pt} /$ tool/81287/r-a-language-and-environment-for-statistical-computing. Accessed October 2, 2020.

40. Santos, K. L.; dos, Panizzon, J.; Cenci, M. M.; Grabowski, G.; Jahno, V. D. 2020. Perdas e desperdícios de alimentos: reflexões sobre o atual cenário brasileiro. Brazilian Journal of Food Technology. 23. https://doi.org/10.1590/1981-6723.13419.

41. Sheahan, M.; Barrett, C. B. 2017. Review: Food loss and waste in Sub-Saharan Africa. Food Policy. 70: 1-12. http://dx.doi.org/10.1016/j.foodpol.2017.03.012.

42. Souza, T. A.; Piato, É. L. 2017. Estratégia no canal de distribuição: análise comparativa entre atacadista distribuidor e de autosserviço. Exacta. https://doi.org/10.5585/exactaep. v15n2.6650.

43. Spagnol, W. A.; Silveira, V.; Pereira, E.; Filho, N. G. 2018. Reducing losses in the fruit and vegetable chains by the analysis of shelf life dynamics. In Brazilian Journal of Food Technology (Vol. 21). Instituto de Tecnologia de Alimentos - ITAL. https://doi.org/10.1590/19816723.07016.

44. Stensgård, A. E.; Hanssen, O. J. Food Waste in Norway 2010-2015. Fredrikstad: [s.n.]. Disponível em: <https://ec.europa.eu/food/sites/food/files/safety/docs/fw_lib_format-rapport2016-eng.pdf>. Acesso em: 6 abr. 2020

45. Stenmarck, Å.; Jensen, C.; Quested, T.; Moates, G.; Cseh, B.; Juul, S.; Parry, A.; Politano, A.; Redlingshofer, B.; Scherhaufer, S.; Silvennoinen, K.; Soethoudt, H.; Zübert, C.; Östergren, K.; Stenmarck, Å.; Jensen, C.; Quested, T.; Moates, G.; Buksti, M.; Cseh, B.; Juul, S.; Parry, A.; Politano, A.; Redlingshofer, B.; Scherhaufer, S.; Silvennoinen, K.; Soethoudt, H.; Zübert, C.; Östergren, K. 2016. Estimates of European Food Waste Levels. Stockholm: European Commission (FP7). http://www.eu-fusions.org/phocadownload/ Publications/Estimates of European food waste levels.pdf. Accessed September 26, 2020.

46. Tonolli, A. J. 2019. Propuesta metodológica para la obtención de indicadores de sustentabilidad de agroecosistemas desde un enfoque multidimensional y sistémico. Revista de la Facultad de Ciencias Agrarias. Universidad Nacional de Cuyo. Mendoza. 51(2): 381-399.

47. Zeileis, A.; Hornik, K.; Wiel, M A.; Hothorn, T. 2008. Implementing a class of permutation tests: The coin package. J Stat Softw. 28(8). http://epub.wu.ac.at/4004/\%5Cnpapers3:// publication/uuid/BF1BBE55-2A35-44D0-96DA-FCCC209A5334. 